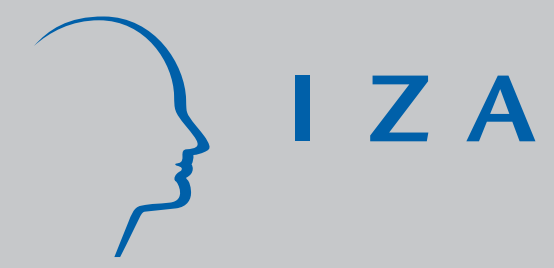

IZA DP No. 4129

Technological Capabilities and Patterns of Cooperation of UK Firms:

A Regional Investigation

Simona lammarino

Mariacristina Piva

Marco Vivarelli

Nick Von Tunzelmann

April 2009 


\title{
Technological Capabilities and Patterns of Cooperation of UK Firms: A Regional Investigation
}

\author{
Simona lammarino \\ SPRU, University of Sussex \\ Mariacristina Piva \\ Università Cattolica del Sacro Cuore, Piacenza \\ Marco Vivarelli \\ Università Cattolica del Sacro Cuore, Piacenza, \\ Max Planck Institute of Economics, Jena, \\ CSGR-Warwick University and IZA \\ Nick Von Tunzelmann \\ SPRU, University of Sussex
}

Discussion Paper No. 4129

April 2009

IZA

P.O. Box 7240

53072 Bonn

Germany

Phone: $+49-228-3894-0$

Fax: +49-228-3894-180

E-mail: iza@iza.org

Any opinions expressed here are those of the author(s) and not those of IZA. Research published in this series may include views on policy, but the institute itself takes no institutional policy positions.

The Institute for the Study of Labor (IZA) in Bonn is a local and virtual international research center and a place of communication between science, politics and business. IZA is an independent nonprofit organization supported by Deutsche Post Foundation. The center is associated with the University of Bonn and offers a stimulating research environment through its international network, workshops and conferences, data service, project support, research visits and doctoral program. IZA engages in (i) original and internationally competitive research in all fields of labor economics, (ii) development of policy concepts, and (iii) dissemination of research results and concepts to the interested public.

IZA Discussion Papers often represent preliminary work and are circulated to encourage discussion. Citation of such a paper should account for its provisional character. A revised version may be available directly from the author. 


\section{ABSTRACT \\ Technological Capabilities and Patterns of Cooperation of UK Firms: A Regional Investigation*}

This paper focuses on the relationship between firms' technological capabilities and different forms of cooperation for innovation by combining the analysis of both micro and meso levels, i.e. the level of the firm and of the geographical region. Our findings, based on the Fourth UK Community Innovation Survey (CIS), provide new insights regarding the relationship between cooperative linkages for innovation and the development of technological capabilities by business units. Firstly, the distinction between competences and capabilities adopted in this paper seems appropriate for going beyond the rather simplistic dichotomy of 'innovative' versus 'non-innovative' firms commonly used in interpreting CIS data. Secondly, we find that the analysis for the UK as a whole masks stark regional differences in terms of intra- and extra-region collaborative linkages and degrees of firms' technological capabilities. These findings may be useful to help policy making to meet the priorities highlighted within the UK Government's framework for Science \& Technology.

JEL Classification: $\quad$ O30, R12

Keywords: cooperation for innovation, technological capabilities, firms, regions

Corresponding author:

Marco Vivarelli

Università Cattolica del Sacro Cuore

Facoltà di Economia

via Emilia Parmense 84

I 29100 Piacenza

Italy

E-mail: marco.vivarelli@unicatt.it

\footnotetext{
* The research leading to these results has received funding from the European Community's Seventh Framework Programme (FP7/2007-2013) under grant agreement $n^{\circ} 216813$.
} 


\section{Introduction}

The evolutionary approach to technical change considers technological capabilities as the outcome of complex interactions among individuals, firms and organisations within a specific socio-economic and institutional framework. At the micro-level, technological capabilities are defined as the knowledge and skills that the firm needs to acquire, use, adapt, improve and create technology (e.g. Lall, 1992; Bell and Pavitt, 1993, 1995). They are built through interactions both within the firm and with external actors (Malerba, 1992).

A shortcoming of most previous studies that have investigated technological capabilities is that these latter are seen at the same time as inputs and outcomes (among others Westphal et al., 1990; Romijn, 1999; Wignaraja, 2002). In this paper it is argued that, in order to evaluate firms' technological capabilities, variables related to outcomes such as the introduction of new products or processes are more appropriate. This distinction comes mainly from the differentiation between competences and capabilities introduced by von Tunzelmann and Wang (2003). Whilst competences are understood as enhanced inputs to produce goods and services, capabilities generally involve learning and the accumulation of new knowledge, and also the integration of behavioural, social and economic factors, as adapted to specific contexts. Consequently, capabilities are to be taken as outputs of adaptive learning processes that are sustained through a variety of external connections and sources for innovation (von Tunzelmann and Wang, 2003, 2007), at least partially embedded in the regional environment of the firm.

This paper investigates the relationship between technological capabilities, competences and different forms of cooperation for innovation by combining the analysis of both micro and meso levels, i.e. the level of the firm and of the geographical region. In particular, the aim is to provide an answer to the following questions: To what extent are the patterns of inter-organisational cooperation for innovation associated with firms' technological capabilities? And is such a relationship between cooperation patterns and technological capabilities influenced by the regional location of firms?

The paper is structured in five sections. The following section summarises the literature on firm-level technological capabilities, innovation linkages and sources external to the firm, emphasising the relevance of the regional environment as an appropriate dimension to study such relationships. Section 3 provides an overview of the data, methodology and assumptions underlying our empirical analysis. Section 4 discusses the results at the firm level taking into account both the overall national context and the specific regional environments. Section 5 offers some concluding remarks and implications of the research here carried out.

\section{Technological capabilities, firms and regions}

Since Nelson and Winter's seminal book (1982), contributions in the area of firm-specific capabilities have proliferated in and among resource-based views, evolutionary economics, the economics and history of technical change, strategic management and, more recently, evolutionary economic geography. The main extensions to orthodox static notions of capabilities involve both interactive and dynamic capabilities. Formally, the interactive dynamic capabilities of firms represent the extent to which the change in their productive capabilities influences or is influenced by the change in the capabilities of other external actors - i.e. consumers, clients, suppliers, etc. - in real time (von 
Tunzelmann and Wang, 2007). The term capabilities has been used variously across different levels of systems from individual to global, to describe a large variety of processes (e.g. 'social capabilities' for growth, see Abramovitz, 1986) and a variety of functions. The present work focuses on technological capabilities as the knowledge and skills that the firm needs to acquire, use, adapt, improve and create technology, interacting with the external environment (e.g. Lall, 1992; Malerba, 1992; Bell and Pavitt, 1993, 1995).

A crucial distinction between competences and capabilities has been introduced by von Tunzelmann and Wang (2003). Competences are understood as stemming from inputs to produce goods and services - in this sense they are pre-set attributes of individuals and firms, with the enhancements typically produced by a different organisation. For example, one may think of firm's endowment of adequate skills as the necessary internal competences to obtain value from $\mathrm{R} \& \mathrm{D}$ and innovation investments (see Piva and Vivarelli, 2009). By the same token, the recruitment of university graduates may be intended as the necessary internal competences for SMEs that want to obtain values from external spillovers (see Acs et al., 1994; Audretsch and Vivarelli, 1994).

Capabilities instead involve learning and accumulation of new knowledge on the part of the firm, and also the integration of behavioural, social and economic factors into a specific set of outcomes. Consequently, capabilities are to be taken as the results of adaptive learning processes that, in their collective dimension, can be highly localised, giving rise to 'system' capabilities, i.e. referring to a specific spatial and industrial setting (Iammarino and McCann, 2009). For instance, an endowment of highly qualified human resources is not a capability per se, but a resource that, through learning, may become a source of technological capabilities for the firm or the system as a whole. In other words, variables related to human resources, or cooperative linkages for innovation with external actors, are to be considered as (among the) determinants of a firm's technological capabilities, rather than as the capabilities themselves (von Tunzelmann and Wang, 2003, 2007).

Different actors (e.g. different firms in an industry) and systems (e.g. different regions in a country) may have dissimilar attitudes for interaction processes, in the form of diverse abilities to learn and to absorb knowledge generated elsewhere. To see this we can make use in Figure 1 of a taxonomy of forms of learning, based on empirical work on US data originally carried out by Malerba (1992).

Figure 1: Internal and external forms of learning for the firm

\begin{tabular}{|l|l|l|}
\hline Source & Internal & External \\
\hline Production & Learning by doing & Learning from spillovers \\
\hline Consumption & Learning by using & Learning from interacting \\
\hline Technology Supply & Learning from R\&D & Learning from S\&T \\
\hline
\end{tabular}

Source: adapted from Malerba (1992).

The rows of the figure conform to a tripartite structure of production, consumption and technology supply - each corresponds to a different form of learning. It should be stressed that in practice learning can take place in all functions of the firm and not just in 'technology' in the narrow sense, e.g. in marketing, in organisation, or in finance. Particularly important for our purposes are the columns that distinguish learning taking place inside the firm from learning external to it that will need to be absorbed in various ways (through the firm's 'absorptive capacity', see Cohen and Levinthal, 1990). Firms can learn horizontally, that is from spillovers from other producers and competitors, or vertically, by interacting with upstream suppliers and downstream users, as well as from 
independent research carried out in the regional, national or international science and technology system by universities and research institutes.

On the other hand, the importance of contextual factors and systemic interactions in the process of generation and diffusion of innovation has long recognised as a key determinant of the technological and economic performance of firms, countries and regions. The significance of the regional dimension of innovation systems has emerged as the logical consequence of the interactive model (Kline and Rosenberg, 1986), which indeed puts the emphasis on the relations with knowledge sources external to the firm. Such relationships - at inter-firm level, between firms and the science infrastructure, between the business sector and the institutional environment, etc. - are strongly influenced by spatial proximity mechanisms that favour processes of polarisation and cumulativeness (see for example Lundvall, 1988; von Hippel, 1988; Cooke et al., 1997).

More recently, the 'open innovation' model (Chesbrough, 2003; Laursen and Salter, 2006) has complemented the innovation system perspective by reinforcing the view that innovative firms draw knowledge from a variety of external sources and linkages, integrating them into their own routines and learning processes, thus achieving more advanced technological capabilities. Latest applications of the capabilities framework to regional innovation systems have emphasised that regions can be considered as spatial congregations of suppliers, producers, consumers, etc., each with their own unique level of capabilities (von Tunzelmann, 2009). Shifting the logic from mere co-location to coevolution, it is argued that, for a region to be progressive, its capabilities need to be interactive - i.e. those of its producers, suppliers and customers need to be in tune - and dynamic - i.e. able to cope with the continuous change of the actors' needs and abilities (ibid.).

The study of technological capabilities at the micro-level, as pursued by the data in this paper, sets the firm at the centre of the analysis (Bell, 1984; Bell and Pavitt, 1995; Hobday, 1995). In addition to interactions and organisational behaviours within the enterprise, the micro-level approach focuses on one-way knowledge and resources flows from the above-mentioned external sources of knowledge into the firm. The underlying assumption is that the single enterprise is too small to affect the behaviour of other (market and non-market) agents, and the external environment is exogenous to the firm.

At the same time, at the meso-level, regional capabilities cannot be considered merely as the sum of individual firm-level capabilities developed in isolation (Lall, 1992; Iammarino et al., 2008; von Tunzelmann, 2009). A region embeds many systemic elements external to the firm that influence its technological capabilities and growth (e.g. Cooke et al., 1997; Howells, 1999; Cooke, 2001; Evangelista et al., 2002; Iammarino, 2005). While the individual firm can regard some of these as exogenous - for instance, the number of graduate students produced in the area - for the region itself this is not so. Nonetheless, the development of regional capabilities shares many of the features of the micro-level: regional learning is a long, uncertain and costly process, showing high pathdependence and cumulativeness. Furthermore, regional learning is strongly conditioned by technological progress achieved elsewhere, especially in less advanced areas (Lall, 1998) or in regions of advanced economies - like some of those encountered within the $\mathrm{UK}$ - that are involved in major restructuring processes.

In spite of the rather copious empirical literature on openness/cooperation linkages and innovation performance at the firm level (see, for example, Cassiman and Veugelers, 2000; Vanhaverbeke et al., 2002; Criscuolo and Haskel, 2003; Belderbos et al., 2004a; Laursen and Salter, 2004, 2006; Faems et al., 2005), surprisingly no evidence has 
emerged on the relationship between different forms of collaborative linkages and different degrees of firms' technological capabilities or, even less so, on the link between openness and the environment of the firm, i.e. its regional location (for an exception, see Simonen and McCann, 2008). In what follows, we try to fill this gap in the literature by investigating technological capabilities after taking into account both firms' linkages for cooperation in R\&D and innovative activities, and their regional location.

\section{Data, methodology and hypotheses}

This paper uses data from the UK Innovation Survey 2005 (as part of the fourth iteration of the wider Community Innovation Survey - CIS4 - covering EU countries), which refers to the period 2002-2004. The survey sampled over 28 thousand UK enterprises with 10 or more employees, had a wide sectoral coverage including both manufacturing and service sectors, and was stratified by Government Office Region in England, along with Scotland, Wales and Northern Ireland. The final representative sample consists of 16,445 firms.

Following the conceptualisation of von Tunzelmann and Wang (2003, 2007) discussed above, technological capabilities at the firm level are signalled by the introduction of a product or process innovation. In other words, to identify firms with technological capabilities in the period of reference of the CIS4 we use the strict (output-oriented) definition of innovators, as in most of the previous literature on the CIS. ${ }^{1}$ Such a definition (based on questions 5 and 9 of the questionnaire) applies if, during the period 2002-04, the enterprise introduced a new or significantly improved product (either a good or a service) and/or new or significantly improved processes for the production or supply of products. In such a case the respondent is here classified as a firm with technological capabilities in relation to such products or processes. ${ }^{2}$ If instead the enterprise has invested in innovative inputs (on the basis of question 13), ${ }^{3}$ but without achieving any innovative output (neither new product nor new process) in the relevant period, it is classified as a firm with technological competences. Finally, if the enterprise has declared neither innovative output nor investment in innovative inputs, it is classified as a technologically inactive firm in the period analysed by the UK CIS4.

The patterns of cooperation for innovation - our main interest in analysing the determinants of technological capabilities - are based on question 18 of the UK questionnaire, which, in line with the Eurostat standardised questionnaire, is devoted to

\footnotetext{
${ }^{1}$ As illustrated by D'Este et al. (2008), there are several reasons why the use of such a definition is appropriate. First, it helps to separate invention from innovation by requiring new products and processes to be of economic value, as shown by the commercialisation requirement (i.e. introduction to market). Second, it is consistent with the standard definition of innovation provided by the Oslo Manual (OECD, 2005). Third, it helps to separate the firm's efforts in innovative activities (as measured by its investment in R\&D-related activities) from the outputs of those activities (as reflected by the market introduction of new products). Thus, it is consistent with the distinction between competences and capabilities adopted here.

${ }^{2}$ Strictly speaking, the product or process innovation thus detected does not amount to the relevant capability - it is the accumulated ability to 'know' (learn) how to effect such an innovation that is the 'capability' in the proper sense. For obvious reasons we do not impose this distinction here.

${ }^{3}$ Question 13 in the UK CIS questionnaire asked if, in the reference period, the firm engaged in any of the following seven innovation activities: (i) intramural R\&D; (ii) acquisition of R\&D; (iii) acquisition of machinery, equipment and software to produce new or significantly improved products; (iv) acquisition of external knowledge (e.g. licensing of patents); (v) training of personnel for the development or introduction of innovations; (vi) expenditure on design functions for the development of new or improved products or processes; and (vii) expenditures on activities for the market preparation and introduction of new or significantly improved products (including market research and launch advertising).
} 
the types of cooperation partners used by the respondent firms, and their location. In fact, cooperation in R\&D and innovative activities may imply a variety of different partners ranging from firms within the same business group, customers, suppliers, competitors and institutional partners such as universities and public labs (e.g. Fritsch and Lukas, 2001; Miotti and Sachwald, 2003; Belderbos et al., 2004b; Piga and Vivarelli, 2003 and 2004; Laursen and Salter, 2006). Seven types of partner are listed in the CIS questionnaire: A) other enterprises within the firm's group; B) suppliers of equipment, materials, services or software; C) clients or customers; D) competitors or other enterprises in the firm's industry; E) consultants, commercial labs, or private R\&D institutes; F) universities or other higher education institutions; G) government or public research institutes.

The eight UK regions considered, in order to have reasonably homogeneous macroregions of roughly the same size, are defined following partial aggregations of NUTS 1 regions: Northern England (North East, North West, Yorkshire and the Humber), Midlands (East Midlands, West Midlands), Eastern England, London, Southern England (South East, South West), Wales, Scotland, and Northern Ireland. The size of our final sample is 15,153, owing to the presence of missing values in the patterns of collaboration. We controlled for the geographical representativeness of our final sample, which turned out to be not statistically different from that of the original sample.

Table 1: Regional distribution of the categorical dependent variable - number of firms and relative percentages (in brackets)

\begin{tabular}{|l|c|c|c|c|c|c|c|c|c|}
\hline & UK & $\begin{array}{l}\text { Northern } \\
\text { England }\end{array}$ & Midlands & $\begin{array}{c}\text { Eastern } \\
\text { England }\end{array}$ & London & $\begin{array}{c}\text { Southern } \\
\text { England }\end{array}$ & Wales & Scotland & $\begin{array}{c}\text { Northern } \\
\text { Ireland }\end{array}$ \\
\hline $\begin{array}{l}\text { Technologically } \\
\text { inactive firm } \\
\text { (value 0) }\end{array}$ & $\begin{array}{c}5,308 \\
(35.03)\end{array}$ & $\begin{array}{c}1,214 \\
(34.82)\end{array}$ & $\begin{array}{c}891 \\
(34.67)\end{array}$ & $\begin{array}{c}461 \\
(35.60)\end{array}$ & $\begin{array}{c}540 \\
(36.58)\end{array}$ & $\begin{array}{c}910 \\
(32.32)\end{array}$ & $\begin{array}{c}348 \\
(34.39)\end{array}$ & $\begin{array}{c}425 \\
(36.51)\end{array}$ & $\begin{array}{c}519 \\
(38.87)\end{array}$ \\
\hline $\begin{array}{l}\text { Firm with } \\
\text { technological } \\
\text { competences } \\
\text { (value 1) }\end{array}$ & $\begin{array}{c}4,105 \\
(27.09)\end{array}$ & $\begin{array}{c}983 \\
(28.20)\end{array}$ & $\begin{array}{c}675 \\
(26.26)\end{array}$ & $\begin{array}{c}326 \\
(25.17)\end{array}$ & $\begin{array}{c}357 \\
(24.19)\end{array}$ & $\begin{array}{c}796 \\
(28.28)\end{array}$ & $\begin{array}{c}293 \\
(28.95)\end{array}$ & $\begin{array}{c}335 \\
(28.78)\end{array}$ & $\begin{array}{c}340 \\
(25.47)\end{array}$ \\
\hline $\begin{array}{l}\text { Firm with } \\
\text { technological } \\
\text { capabilities } \\
\text { (value 2) }\end{array}$ & $\begin{array}{c}5,740 \\
\text { Total }\end{array}$ & $\begin{array}{c}1,289 \\
(36.98)\end{array}$ & $\begin{array}{c}1,004 \\
(39.07)\end{array}$ & $\begin{array}{c}508 \\
(39.23)\end{array}$ & $\begin{array}{c}579 \\
(39.23)\end{array}$ & $\begin{array}{c}1,109 \\
(39.40)\end{array}$ & $\begin{array}{c}371 \\
(36.66)\end{array}$ & $\begin{array}{c}404 \\
(34.71)\end{array}$ & $\begin{array}{c}476 \\
(35.66)\end{array}$ \\
\hline
\end{tabular}


Our dependent variable is a categorical ordered variable which assumes the following values: 0 in the case of a technologically inactive firm; 1 in the case of a firm with technological competences; 2 in the case of a firm with technological capabilities. Table 1 displays the regional distribution of the three categories of firms. It is interesting to note that the shares of firms belonging to each group are rather equally distributed across regions, driving the choice of the estimation method - an ordered logistic model.

Dummies were created for each of the cooperation partners reported in question 18, aggregating universities/other higher education institutions and government/public research institutes into one category. ${ }^{4}$ Two location levels for each of the six partners were taken into account: local/regional, that is within approximately 100 miles of the surveyed enterprise (as defined in the CIS questionnaire); extra-regional (i.e. national/international). The total number of collaboration dummies is thus 12 .

While the relationship between the different forms of cooperation and the technological status of the firm is at the core of our investigation, other determinants of innovative performance must be considered. In particular, our control variables are the following:

- $\quad$ Size: firm size in terms of employment (continuous variable).

The Schumpeterian notion that large firms are more likely both to undertake and to succeed in innovative activities has constituted a constant theme in the literature (Schumpeter, 1943). Such a notion has been initially challenged from a theoretical point of view (Arrow, 1962), and then proposed again in terms of scale and scope economies in R\&D investments (Cohen and Klepper, 1996). In the last few decades mixed empirical evidence has been found to support the Schumpeterian hypothesis (e.g. Cohen and Levin, 1989; Kleinknecht and Reijnen, 1991; Audretsch, 1995; Breschi et al., 2000).

- $\quad$ Group: whether the firm is part of an enterprise group (dummy).

Various studies have recognised that the group form of organisation tends to play an important role in promoting and supporting innovation (see, for instance, Filatotchev et al., 2003; Piga and Vivarelli, 2004).

- Internationalisation: extent of internationalisation of the markets served by the firm, in terms of whether the firm sells products/services outside the national market (dummy).

Indeed, global competition can spur innovation and capabilities, while technologically inactive firms are doomed to be excluded from the international arena (e.g. Archibugi and Iammarino, 1999; Narula and Zanfei, 2003).

- $\quad$ Start-up: whether the firm was established after $1^{\text {st }}$ January 2000 (dummy).

The debate on the so-called New Technology Based Firms (NTBFs) points out how - at least in some sectors - young companies may be at the core of the innovation process (see, for instance, Storey and Tether, 1998; Colombo et al., 2004; Colombo and Grilli, 2005).

- Human capital: firm-specific skills in terms of proportion of employees educated to degree level or above (continuous variable).

\footnotetext{
${ }^{4}$ For most estimations, the coefficients were similar between these two categories when (in calculations not reported here) we tried estimating them both. On the occasions where they differed and only one was statistically significant, we will refer to the impact of universities or of public research institutes separately.
} 
Human capital is seen as complementary to innovation and generating a superadditive effect in terms of both innovative and economic performance (e.g. Acemoglu, 1998; Machin and Van Reenen, 1998; Piva and Vivarelli, 2004; Piva et al., 2005).

The analysis also includes regional dummies in the aggregated model, and sectoral dummies in all specifications. ${ }^{5}$ The list of all variables used in the analysis is reported in Appendix 1.

In accordance with the nature of the dependent variables, ordered logistic regressions were run. ${ }^{6}$ The following specification has been tested for the country as a whole:

Technological status $=\alpha+\beta_{1} \log ($ employment $)+\beta_{2}($ group $)+\beta_{3}($ internationalisation $)+$ $\beta_{4}($ start-up $)+\beta_{5}($ human_capital $)+\beta_{6}($ cooperation_dummies $)+\beta_{7}($ sectoral_dummies $)+$ $\beta_{8}$ (regional_dummies $)+\varepsilon$

To explore whether and to what extent the relationship between technological competences/capabilities and different cooperation patterns is region-specific, the same model was also estimated for each of the eight UK regions.

\section{Technological capabilities and cooperation patterns: results}

This section reports the results on the differences across firms and regions, in terms of competences and capabilities for innovation, once we explicitly consider a number of factors, and particularly collaborative linkages, which may influence the dependent variable.

First of all, it is important to note that our results are especially driven by the category of firms with technological capabilities. In fact, the cut-off as between technologically inactive firms and those with competences (enhanced inputs but lacking technological outputs) is generally not statistically significant in the ordered logistic regressions for the country as a whole and for any region in the regional estimations. ${ }^{7}$ On the other hand, the few peculiar features that characterise the group of firms with technological competences with respect to the other two firm groups support the conjecture that these firms represent somehow an intermediate innovative behaviour (see also D'Este et al., 2008). This sits comfortably with our choice of distinguishing the three categories of firms according to

\footnotetext{
${ }^{5}$ We followed the clustering criteria used by the Department for Innovation, University and Skills (DIUS): Primary sector; Engineering-based manufacturing; Other manufacturing; Construction; Retail \& distribution; Knowledge-intensive services; Other services. The sectoral distribution of the three categories of firms is reported in Appendix 2.

${ }^{6}$ Assuming that the dependent variable is an ordered one, we opted for the ordered logistic model. However, multinomial logistic regressions were also run with the category of technologically inactive firms as the reference (category 0). The results from the multinomial, and the estimated predicted probabilities of both the multinomial and the ordered logistic models, supported our choice of the latter, as the probability distribution between the two estimation methods is not substantially different. Furthermore, a Brant test to verify the parallel regression assumption (also called the proportional odds assumption) was performed after the ordered model. The test compares slope coefficients of the $J$ - 1 binary logits implied by the ordered regression model. This test can only be computed if all the independent variables in the ordered model are retained in all the implied binary models. For this reason, it was not possible to compute the test in all the regional models, nevertheless - where feasible - the test provided evidence that the parallel regression assumption has not been violated.

${ }^{7}$ Equivalent results hold in the unreported multinomial logit regressions, where the coefficients for firms with technological competences (category 1) are in general smaller and/or with lower significance levels than those for firms with technological capabilities (category 2).
} 
their technological status, which seems to provide a better grasp of the information on innovation contained in the CIS data.

Table 2: Determinants of Firms’ Capabilities, UK with Regional Dummies

Ordered Logistic Regression

Categorical Ordered Dependent Variable: 0 = Technologically inactive firm; 1 = Firm with technological competences; 2 = Firm with technological capabilities

(1)

$\begin{array}{ll} & \\ \text { Ln(Employment) } & 0.12^{* * *} \\ & (9.60) \\ \text { Group } & 0.23^{* * *} \\ & (6.27) \\ \text { Internationalisation } & 0.56^{* * *} \\ & (14.59) \\ \text { Start-up } & 0.10^{* *} \\ & (2.26) \\ \text { Human capital } & 1.41^{* * *} \\ & (16.99)\end{array}$

\section{Cooperation partners for innovation}

\begin{tabular}{|c|c|c|c|}
\hline $\begin{array}{l}\text { A: other enterp. within } \\
\text { group LOCAL }\end{array}$ & $\begin{array}{l}0.40^{* * *} \\
(2.90)\end{array}$ & Other services & $\begin{array}{c}-0.72 * * * \\
(12.66)\end{array}$ \\
\hline $\begin{array}{l}\text { A: other enterp. within } \\
\text { group NOT LOCAL }\end{array}$ & $\begin{array}{l}0.32^{* * * *} \\
(2.62)\end{array}$ & & \\
\hline B: suppliers LOCAL & $\begin{array}{l}0.44^{* * *} \\
(3.43)\end{array}$ & Regional dummies & yes*** \\
\hline B: suppliers NOT LOCAL & $\begin{array}{l}1.16^{* * *} \\
(10.81)\end{array}$ & North England & $\begin{array}{l}0.11 \\
(1.63)\end{array}$ \\
\hline C: clients LOCAL & $\begin{array}{l}0.44 * * * \\
(3.38)\end{array}$ & Midlands & $\begin{array}{l}0.14^{*} \\
(1.95)\end{array}$ \\
\hline C: clients NOT LOCAL & $\begin{array}{l}0.69 * * * \\
(6.16)\end{array}$ & Eastern England & $\begin{array}{l}0.09 \\
(1.12)\end{array}$ \\
\hline D: competitors LOCAL & $\begin{array}{l}-0.27^{*} \\
(1.69)\end{array}$ & London & $\begin{array}{l}-0.16^{* *} \\
(2.11)\end{array}$ \\
\hline D: competitors NOT LOCAL & $\begin{array}{l}0.05 \\
(0.38)\end{array}$ & South England & $\begin{array}{l}0.20^{* * *} \\
(2.88)\end{array}$ \\
\hline E: consultants LOCAL & $\begin{array}{l}0.14 \\
(0.92)\end{array}$ & Wales & $\begin{array}{l}0.13 \\
(1.54)\end{array}$ \\
\hline E: consultants NOT LOCAL & $\begin{array}{l}-0.02 \\
(0.12)\end{array}$ & Scotland & - \\
\hline $\begin{array}{l}\text { F+G: universities\&pub.res. } \\
\text { LOCAL }\end{array}$ & $\begin{array}{l}0.46^{* * * *} \\
(3.47)\end{array}$ & Northern Ireland & $\begin{array}{l}0.14^{*} \\
(1.80)\end{array}$ \\
\hline F+G: universities\&pub.res. & $0.34 * *$ & & \\
\hline NOT LOCAL & $(2.43)$ & & \\
\hline $\operatorname{LR} \chi^{2}$ (d.f.) & 30) $3,854 * * *$ & & \\
\hline Pseudo $\mathrm{R}^{2}$ & 0.12 & & \\
\hline Observations & 15,153 & & \\
\hline
\end{tabular}

$\begin{array}{ll}\text { Sectoral dummies } & \text { yes*** } \\ & -1.06^{* * *} \\ \text { Primary sector } & (7.67) \\ & - \\ \text { Engineering-based manuf. } & \\ & -0.01 \\ \text { Other manufacturing } & (0.20) \\ & -0.97 * * * \\ \text { Construction } & (13.87) \\ & -0.82^{* * *} \\ \text { Retail \& distribution } & (13.54) \\ & -0.28 * * * \\ \text { Know.-intensive services } & (4.37) \\ & -0.72 * * * \\ \text { Other services } & (12.66)\end{array}$

(2) 
Table 2 shows the results for the aggregate model - i.e. for the UK as a whole. In line with the theoretical expectations discussed above, all the variables related to firm characteristics are highly significant at $1 \%$ level (with the exception of start-up, with a level of significance of 5\%), indicating a positive impact on the likelihood of firms to be classified as firms with technological capabilities. As far as the independent variables concerning cooperation partners are concerned, linkages with other enterprises within the group, suppliers, clients, and public research and higher education institutions are all positive and highly significant at both local and extra-regional level.

Consistently with the previous literature, both the dummy for belonging to a group and the two dummies indicating cooperation with firms within the same business group turn out to be statistically significant at $1 \%$ level, pointing to the strategic role of group relationships in enhancing the technological status of the individual firms involved. Interestingly enough, the enforcement role of cooperation appears more obvious for firms in the same business group and also located at a short distance. ${ }^{8}$

In contrast, geographical distance does not seem to play a role in the vertical cooperative links, where actually the coefficients related to extra-regional suppliers and customers give a result that is higher in magnitude than those related to local partners. However, vertical relationships come out as highly significant in all four cases.

By contrast, horizontal cooperative links with competitors and consultants do not seem to play a significant role in enhancing the probability that a firm achieves technological capabilities. In other words, while innovation seems to be reinforced by collaborations along the value chains, once we turn our attention to the horizontal dimension, rivalry seems to dominate. It is interesting to note, though, that cooperation with extra-regional consultants turns out to have a much stronger effect in increasing the likelihood of being a firm with technological competences. This can be explained as firms in the stage of investing in innovation inputs tending to rely much more on the advice provided by external consultants in order to achieve commercial success. ${ }^{9}$

Finally, cooperation with universities and public research institutes turns out to be significant and positively affected by the close proximity of the involved partners. This is not surprising, due to the localised nature of labour markets.

In line with expectations, the sectoral dummies indicate that the impact is greatest in engineering-based manufacturing, which is the chosen reference category. Turning to the regional dummies, relative to Scotland - here used as the reference region - all regions except London show a positive sign of the coefficient, although some of them are not significant. Interestingly, the London location seems to have an even greater negative effect on the category of firms having technological competences: in other words, being located in the capital city decreases the probability for firms to be classified as 'technologically active' in general. However, in interpreting these regional dummies it has to be borne in mind that much of the variance is likely to be picked up by the other variables included in the estimation, since many of these also differ among regions.

Table 3 provides the estimates for the individual UK regions. As we can see, the cooperation variables show remarkable differences in influencing the technological status of firms, according to the specific regional context.

\footnotetext{
${ }^{8}$ The correspondent coefficients turn out to be 0.40 and 0.32 for local and non-local firms, respectively.

9 This result is even stronger in the multinomial regressions, where the coefficient of extra-regional consultants for firms in category 1 is higher than for those in category 2 , and significant at $1 \%$.
} 
Table 3: Determinants of Firms' Capabilities, Regions of UK

Ordered Logistic Regression: Regional analysis

Categorical Ordered Dependent Variable: 0 = Technologically inactive firm; 1 = Firm with technological competences; 2 = Firm with technological capabilities

\begin{tabular}{|c|c|c|c|c|c|c|c|c|}
\hline & (1) & (2) & (3) & (4) & (5) & (6) & (7) & (8) \\
\hline & Northern & Midlands & Eastern & London & Southern & Wales & Scotland & Northern \\
\hline & England & & England & & England & & & Ireland \\
\hline \multirow[t]{2}{*}{ Ln(Employment) } & $0.12 * * *$ & $0.15 * * *$ & $0.16^{* * *}$ & $0.10 * * *$ & $0.11^{* * *}$ & 0.08 & 0.07 & $0.14^{* *}$ \\
\hline & $(4.62)$ & $(4.82)$ & $(3.55)$ & $(2.98)$ & $(4.27)$ & $(1.34)$ & $(1.48)$ & $(2.53)$ \\
\hline \multirow[t]{2}{*}{ Group } & $0.22 * * *$ & $0.20 * *$ & $0.26 * *$ & $0.45^{* * *}$ & 0.13 & 0.21 & $0.27 * *$ & 0.21 \\
\hline & $(2.79)$ & (2.18) & (1.99) & $(4.05)$ & $(1.52)$ & (1.37) & $(2.01)$ & $(1.56)$ \\
\hline \multirow[t]{2}{*}{ Internationalisation } & $0.61 * * *$ & $0.56 * * *$ & $0.66 * * *$ & $0.32 * *$ & $0.61 * * *$ & $0.88 * * *$ & $0.75 * * *$ & $0.39 * * *$ \\
\hline & (7.34) & $(5.84)$ & $(4.90)$ & $(2.77)$ & $(6.61)$ & $(5.43)$ & $(5.35)$ & (3.23) \\
\hline \multirow[t]{2}{*}{ Start-up } & $0.26 * * *$ & 0.04 & 0.08 & $0.26^{*}$ & -0.07 & 0.03 & 0.17 & 0.07 \\
\hline & $(2.88)$ & $(0.39)$ & $(0.49)$ & $(1.73)$ & $(0.62)$ & $(0.16)$ & $(1.00)$ & $(0.44)$ \\
\hline \multirow[t]{2}{*}{ Human capital } & $1.89 * * *$ & $1.58 * * *$ & $1.76 * * *$ & $1.06 * * *$ & $1.41 * * *$ & $0.82 * *$ & $0.93 * * *$ & $1.80 * * *$ \\
\hline & $(9.26)$ & $(7.02)$ & $(5.62)$ & $(5.79)$ & $(7.26)$ & $(2.36)$ & $(3.26)$ & $(5.44)$ \\
\hline \multicolumn{9}{|c|}{ Cooperation partners for innovation } \\
\hline \multirow[t]{2}{*}{ - A: other enterp. LOCAL } & 0.22 & 0.13 & 0.43 & 0.32 & 0.30 & $0.89 *$ & $1.35 * * *$ & 1.03 \\
\hline & $(0.73)$ & (0.39) & $(0.87)$ & $(0.75)$ & $(0.89)$ & (1.73) & $(2.92)$ & (1.60) \\
\hline \multirow[t]{2}{*}{ - A: other enterp. NOT LOCAL } & $0.41 *$ & 0.55 & -0.20 & 0.03 & $1.11 * * *$ & -0.15 & -0.24 & 0.82 \\
\hline & (1.67) & (1.47) & $(0.46)$ & $(0.11)$ & (3.61) & $(0.28)$ & $(0.49)$ & $(0.88)$ \\
\hline \multirow{2}{*}{ - B: suppliers LOCAL } & $0.67 * *$ & $0.63^{*}$ & 0.65 & $0.78 * *$ & -0.44 & $0.91 *$ & 0.66 & 0.31 \\
\hline & $(2.45)$ & $(1.77)$ & $(1.51)$ & $(2.05)$ & $(1.47)$ & (1.68) & (1.53) & $(0.62)$ \\
\hline \multirow[t]{2}{*}{ - B: suppliers NOT LOCAL } & $0.83 * * *$ & $1.51 * * *$ & $1.52 * * *$ & $1.40 * * *$ & $1.23 * * *$ & $1.01^{* *}$ & $0.79 * *$ & $1.71 * * *$ \\
\hline & (3.76) & $(4.36)$ & (3.91) & (4.59) & (5.19) & (2.25) & (1.99) & (3.27) \\
\hline \multirow[t]{2}{*}{ - C: clients LOCAL } & -0.10 & $1.00 * * *$ & $0.99 * *$ & 0.09 & $0.82 * * *$ & 0.37 & 0.10 & $0.90^{*}$ \\
\hline & $(0.36)$ & (2.93) & $(2.14)$ & $(0.21)$ & $(2.58)$ & $(0.73)$ & $(0.22)$ & $(1.72)$ \\
\hline \multirow[t]{2}{*}{ - C: clients NOT LOCAL } & $0.56^{* *}$ & $1.37 * * *$ & $0.81^{* *}$ & 0.44 & 0.27 & 0.16 & $0.96 * *$ & $2.24 * * *$ \\
\hline & $(2.49)$ & $(4.36)$ & (2.07) & (1.36) & (1.00) & $(0.33)$ & $(2.41)$ & $(2.96)$ \\
\hline \multirow[t]{2}{*}{ - D: competitors LOCAL } & -0.02 & -0.39 & -0.16 & -0.39 & -0.60 & -0.58 & -0.40 & -0.70 \\
\hline & $(0.07)$ & $(0.98)$ & $(0.26)$ & $(0.83)$ & $(1.36)$ & (1.01) & $(0.75)$ & $(0.11)$ \\
\hline \multirow[t]{2}{*}{ - D: competitors NOT LOCAL } & 0.20 & $-0.99 * * *$ & -0.71 & $0.70 *$ & $1.03 * * *$ & 0.48 & -0.56 & -0.69 \\
\hline & $(0.76)$ & $(2.88)$ & (1.60) & (1.69) & (3.30) & (0.99) & (1.16) & (0.96) \\
\hline
\end{tabular}




\begin{tabular}{|c|c|c|c|c|c|c|c|c|}
\hline - E: consultants LOCAL & $\begin{array}{l}0.65^{* *} \\
(1.97)\end{array}$ & $\begin{array}{l}-0.08 \\
(0.20)\end{array}$ & $\begin{array}{l}-0.45 \\
(0.77)\end{array}$ & $\begin{array}{l}-0.22 \\
(0.52)\end{array}$ & $\begin{array}{l}0.73^{*} \\
(1.78)\end{array}$ & $\begin{array}{l}0.49 \\
(0.76)\end{array}$ & $\begin{array}{l}-0.08 \\
(0.17)\end{array}$ & $\begin{array}{l}-0.92 \\
(1.38)\end{array}$ \\
\hline - E: consultants NOT LOCAL & $\begin{array}{l}0.61^{* *} \\
(2.04)\end{array}$ & $\begin{array}{l}-0.75 * * \\
(2.06)\end{array}$ & $\begin{array}{l}0.20 \\
(0.39)\end{array}$ & $\begin{array}{l}-0.29 \\
(0.68)\end{array}$ & $\begin{array}{l}-0.24 \\
(0.74)\end{array}$ & $\begin{array}{l}0.38 \\
(0.70)\end{array}$ & $\begin{array}{l}0.36 \\
(0.66)\end{array}$ & $\begin{array}{l}1.02 \\
(1.04)\end{array}$ \\
\hline - F+G: universities\&pub.res. & $0.81 * * *$ & 0.04 & 0.62 & 0.10 & 0.47 & -0.03 & 0.56 & 0.54 \\
\hline LOCAL & $(3.17)$ & $(0.11)$ & $(1.16)$ & $(0.22)$ & $(1.29)$ & $(0.08)$ & $(1.19)$ & $(1.03)$ \\
\hline - F+G: universities\&pub.res. & 0.08 & $0.91 * *$ & 0.47 & 0.24 & 0.26 & 0.66 & 0.50 & $-1.65 *$ \\
\hline NOT LOCAL & $(0.30)$ & $(2.50)$ & $(1.04)$ & $(0.59)$ & $(0.75)$ & $(1.10)$ & $(1.04)$ & $(1.77)$ \\
\hline Sectoral dummies & yes*** & yes*** & yes*** & yes*** & yes*** & yes*** & yes*** & yes*** \\
\hline Primary sector & $\begin{array}{l}-1.13 * * * \\
(3.20)\end{array}$ & $\begin{array}{l}-0.84^{* *} \\
(2.10)\end{array}$ & $\begin{array}{l}-0.73 \\
(1.46)\end{array}$ & $\begin{array}{l}-1.84 * * * \\
(3.76)\end{array}$ & $\begin{array}{l}-0.70^{*} \\
(1.89)\end{array}$ & $\begin{array}{l}-0.97 \\
(1.60)\end{array}$ & $\begin{array}{l}-1.23^{* * * *} \\
(3.91)\end{array}$ & $\begin{array}{l}-1.29 * * * \\
(3.17)\end{array}$ \\
\hline Engineering-based manuf. & - & - & - & - & - & - & - & - \\
\hline Other manufacturing & $\begin{array}{l}1.18 \\
(1.57)\end{array}$ & $\begin{array}{l}-0.02 \\
(0.18)\end{array}$ & $\begin{array}{l}0.06 \\
(0.30)\end{array}$ & $\begin{array}{l}-0.70 * * \\
(2.40)\end{array}$ & $\begin{array}{l}0.08 \\
(0.55)\end{array}$ & $\begin{array}{l}0.02 \\
(0.08)\end{array}$ & $\begin{array}{l}-0.22 \\
(0.99)\end{array}$ & $\begin{array}{l}-0.19 \\
(0.90)\end{array}$ \\
\hline Construction & $\begin{array}{l}-0.66 * * * \\
(4.67)\end{array}$ & $\begin{array}{l}-0.98 * * * \\
(5.95)\end{array}$ & $\begin{array}{l}-1.16^{* * * *} \\
(4.49)\end{array}$ & $\begin{array}{l}-1.60 * * * \\
(4.99)\end{array}$ & $\begin{array}{l}-1.06^{* * * *} \\
(6.21)\end{array}$ & $\begin{array}{l}-1.33^{* * * *} \\
(5.02)\end{array}$ & $\begin{array}{l}-0.87^{* * * *} \\
(3.52)\end{array}$ & $\begin{array}{l}-0.97 * * * \\
(4.22)\end{array}$ \\
\hline Retail \& distribution & $\begin{array}{l}-0.65 * * * \\
(5.23)\end{array}$ & $\begin{array}{l}-0.82 * * \\
(5.79)\end{array}$ & $\begin{array}{l}-0.71^{* * *} \\
(3.45)\end{array}$ & $\begin{array}{l}-1.40^{* * * *} \\
(4.92)\end{array}$ & $\begin{array}{l}-0.73^{* * * *} \\
(5.09)\end{array}$ & $\begin{array}{l}-1.02 * * * \\
(4.43)\end{array}$ & $\begin{array}{l}-0.74^{* * * *} \\
(3.19)\end{array}$ & $\begin{array}{l}-1.07^{* * *} \\
(5.18)\end{array}$ \\
\hline Knowledge-intensive services & $\begin{array}{l}-0.19 \\
(1.44)\end{array}$ & $\begin{array}{l}-0.32 * * \\
(2.17)\end{array}$ & $\begin{array}{l}-0.40^{*} \\
(1.80)\end{array}$ & $\begin{array}{l}-1.04^{* * *} \\
(3.80)\end{array}$ & $\begin{array}{l}-0.24^{*} \\
(1.65)\end{array}$ & $\begin{array}{l}-0.14 \\
(0.58)\end{array}$ & $\begin{array}{l}-0.20 \\
(0.87)\end{array}$ & $\begin{array}{l}0.16 \\
(0.61)\end{array}$ \\
\hline Other services & $\begin{array}{l}-0.48^{* * * *} \\
(4.22)\end{array}$ & $\begin{array}{l}-0.81^{* * *} \\
(6.14)\end{array}$ & $\begin{array}{l}-0.89 * * * \\
(4.45)\end{array}$ & $\begin{array}{l}-1.32 * * * \\
(4.91)\end{array}$ & $\begin{array}{l}-0.71 * * \\
(5.23)\end{array}$ & $\begin{array}{l}-0.80 * * * \\
(3.76)\end{array}$ & $\begin{array}{l}-0.74^{* * *} \\
(3.52)\end{array}$ & $\begin{array}{l}-0.74^{* * *} \\
(3.45)\end{array}$ \\
\hline LR $\chi^{2}$ (d.f.) & $\chi^{2}(23) 891^{* * *}$ & (23) $700 * * *$ & (23) $418 * * *$ & (23) $323 * * *$ & (23) $801^{* * *}$ & (23) $298 * * *$ & (23) $293 * * *$ & (23) $341 * * *$ \\
\hline Pseudo $\mathrm{R}^{2}$ & 0.12 & 0.13 & 0.15 & 0.10 & 0.13 & 0.14 & 0.12 & 0.12 \\
\hline Observations & 3,486 & 2,570 & 1,295 & 1,476 & 2,815 & 1,012 & 1,164 & 1,335 \\
\hline
\end{tabular}

\section{Notes:}

- In brackets: z- statistics; * = $10 \%$ significant, ** = $5 \%$ significant, $* * *=1 \%$ significant.

- 7 sectoral dummies are included (DTI sectoral classification).

- yes*** for sectoral dummies reporting that they are jointly significant at $1 \%$ level. 
In fact, London emerges as a divergent case in terms of cooperation for innovation and technological capabilities. The only type of cooperative linkage that turns out to be significant is that with suppliers at both local and, even more, extra-regional level. This would suggest that a firm's location in the metropolitan area does not tend to entail a strong relationship between collaborative linkages and its technological capabilities (see Schienstock, 2009, for similar results on firms' capabilities in city-regions). Indeed, the London metropolitan area has to be understood more as an "accumulation node" of global economic and financial transactions, rather than a regional economic system. Therefore, the complex structure of the capital city and its articulated relationships both with other regions in the UK and with the rest of the world suggest that London's boundaries per se do not set up significant interactions for local firms in terms of either markets or social organisations (Budd, 2006), but rather comprise an array of control and management nodes for global transactions and businesses (Newman and Thornley, 2005). In this context, London firms' innovative strengths are driven mostly by high levels of other variables such as size, group membership, foreign sales and, especially, human capital.

Considering Southern England, the impact of collaborative relations on firms' capabilities is much more evident than for London, but the strongest of these links are mostly extra-regional rather than local. The only notable exception is intra-regional collaborations with clients, which strongly increase the probability of the firm being classified as having technological capabilities. The peculiar strongly positive effect of horizontal collaboration with extra-regional competitors may perhaps be explained by an 'M4 corridor effect' that could reflect national and international strategic technological alliances among large and/or multinational enterprises.

In the Eastern England region, the likelihood that firms display technological capabilities is positively influenced by collaborations with extra-regional suppliers and with both local and non-local clients. This latter effect might be spurred by the presence of the 'Cambridge cluster', whose successful innovative performance is however counterbalanced by some lagging behind of the rest of the region (Gray et al., 2006).

As far as vertical cooperation is concerned, the results for the Midlands are similar to those for Eastern England, though with more significant linkages with clients and an additional positive impact of local suppliers on firms' technological capabilities (significant at $10 \%$ level). A peculiar feature of the Midlands is the positive effect on firms' capabilities of linkages with universities and public research located outside the region. Indeed, in recent decades the Midlands - characterised until the 1970s and '80s as the Fordist heartland of the country, particularly for automotive and metal manufacturing, and by coal-based industry - have gone through a period of post-industrial economic restructuring which, more recently, has sparked local innovation potential and connectivity among firms (AWM, 2004; Green and Berkeley, 2006; Hardill et al., 2006). This path of evolution of the regional industrial structure may also underlie the negative and significant effect on firms' capabilities of linkages with competitors and consultants external to the region, indicating that the firms located in the Midlands are particularly struggling in the international technological race. 
Northern England turns out to be the UK region where the association between the different determinants and firm-level technological capabilities is the most striking. The start-up variable is strongly significant and positively affecting the probability of firms having technological capabilities, driving the effect at the country level at large. This might be interpreted in terms of a process of gradual replacement of declining and mature industries and shifts of the regional industrial structure towards more advanced manufacturing and service sectors. This seems to be further supported by the positive and significant sign on cooperative linkages with both regional and extra-regional private research and consultants, which again determines the result at the national level. Remarkably, the North is also the only region where the probability of being a firm with technological capabilities is strongly increased by collaborations with local public research institutes and universities, once more driving the result for the UK as a whole. Such a result should be interpreted in the light of the 'Northern Way' strategy implemented for the three Northern English regions (North East, North West and Yorkshire and Humber) since the start of this decade. The 'Northern Way' is mainly aimed at strengthening intra-regional coordination in economic and social development efforts, with a strong emphasis on the local knowledge base, and the local integration of innovation, research and education and training. The remarkable concentration of highrank universities in the region (among others Manchester, Newcastle, Leeds, Sheffield) has acted as one of the main pillars of this strategy (e.g. Byrne and Benneworth, 2006; Wilson and Baker, 2006; Gore and Jones, 2006).

A strong multinational presence and a high degree of internationalisation drive the patterns of collaboration for innovation in the regions of Wales and Scotland. In the case of Wales, cooperation influences the likelihood that firms are in the category of those with technological capabilities, particularly as far as linkages with suppliers (local and especially extra-regional) are concerned. In Scotland - and to a lesser extent also in Wales - the impact of local collaboration within the enterprise group suggests a relatively highly integrated corporate strategy for innovation in the regional system. ${ }^{10}$ Similarly to Wales, Scotland shows a positive impact of cooperation with extra-local suppliers, and in addition with non-local clients, possibly due to corporate vertical integration of the transnational enterprises located in the region.

A similar pattern to Scotland emerges for Northern Ireland's vertical cooperative linkages, with strongly positive coefficients for collaborations with extra-regional suppliers and clients. This is not surprising, due to the strong economic integration of Northern Ireland with the other UK regions.

\section{Conclusions}

The aim of this paper has been to investigate the relationship between different forms of collaborative linkages and different degrees of firms' technological capabilities - defined in terms of outputs of learning processes - considering in particular the role of the environment of the firm in the form of its regional location.

\footnotetext{
${ }^{10}$ Interestingly, the linkages within the group are instead highly significant at the extra-regional level in Southern England, indicating a rather high intra-group integration beyond regional boundaries (with headquarters mainly located in the South East of England).
} 
Our findings indicate that highly significant results obtained for the UK as a whole actually mask considerable differences among the regions. In particular, the findings show remarkable regional specificities in terms of the association between collaborative patterns and technological capabilities at the firm level. For instance, UK regions such as the Midlands and, even more, Northern England show the greatest evidence of utilising a richer variety of collaborative linkages at the firm level to restructure their regional systems of innovation and enhance their technological capabilities. On the contrary, the globalised metropolitan region of London displays a weak association between cooperative patterns and the technological status of firms located there. By the same token, local networking is also less crucial in peripheral - but highly internationalised regions such as Scotland, Wales and Northern Ireland.

The main implication for regional analysis is that the scope for interaction varies greatly among regions and in some contexts is potentially huge, provided that private and public resources are devoted to identifying and facilitating the most effective linkages for the observed region. In other words, managing regional interactions and cooperation in order to enhance firms' technological capabilities is not a free lunch.

In particular, regional policy should start from the distinction drawn between technological competences and technological capabilities, being aware that simply marshalling the resources - i.e. increasing innovation inputs - cannot be enough, and finally recognizing that fuelling the link between cooperative networking and technological capabilities is a policy target that has to be tailored to the specific features of a given regional economic system. 


\section{References}

Abramovitz, M. (1986), “Catching up, Forging Ahead, and Falling Behind”, Journal of Economic History, vol.46, pp.385-406.

Acemoglu, D. (1998), "Why Do New Technologies Complement Skills? Directed Technical Change and Wage Inequality", Quarterly Journal of Economics, vol.113, pp.1055-1090.

Acs, Z., Audretsch, D.B. and Feldman, M. (1994), "The Recipients of R\&D Spill-overs: Firm Size and Innovation”, Review of Economics and Statistics, vol.76, pp.336-340.

Archibugi, D. and Iammarino, S. (1999), "The Policy Implications of the Globalisation of Innovation”, Research Policy, vol.28, pp.317-336.

Arrow, K. (1962), "Economic Welfare and the Allocation of Resources for Invention”, in Nelson, R. (Ed.), The Rate and Direction of Inventive Activity, Princeton University Press, Princeton NJ.

Audretsch, D.B. (1995), Innovation and Industry Evolution, MIT Press, Cambridge MA.

Audretsch, D.B. and Vivarelli, M. (1994), "Small Firms and R\&D Spillovers: Evidence from Italy”, Revue d'Economie Industrielle, vol.67, pp.225-237.

AWM (2004), Advantage West Midlands, www.advantagewm.co.uk

Bell, M. (1984), "Learning and the Accumulation of Industrial Technological Capability in Developing Countries”, in Fransman, M. and King, K. (Eds), Technological Capability in the Third World, Macmillan, London, pp.187-209.

Bell, M. and Pavitt, K. (1993), "Technological Accumulation and Industrial Growth: Contrast between Developed and Developing Countries”, Industrial and Corporate Change, vol.2, pp.157-210.

Bell, M. and Pavitt, K. (1995), “The Development of Technological Capabilities”, in Haque, I.U. (Ed.), Trade, Technology and International Competitiveness, World Bank, Washington, pp.69-101.

Belderbos, R., Carree, M. and Lokshin, B. (2004a), “Cooperative R\&D and Firm Performance”, Research Policy, vol.33, pp.1477-1492.

Belderbos, R., Carree, M., Diederen, B., Lokshin, B. and Veugelers, R., (2004b), "Heterogeneity in R\&D Cooperation Strategies", International Journal of Industrial Organization, vol.22, pp.1237-1263.

Breschi, S., Malerba, F. and Orsenigo, L. (2000), “Technological Regimes and Schumpeterian Patterns of Innovation”, Economic Journal, vol.110, pp.388-410.

Budd, L. (2006), “London: From City-state to City-region?”, in Hardill, I., Benneworth, P., Baker, M. and Budd, L. (Eds), The Rise of the English Regions?, Routledge, London, pp.245266.

Byrne, D, and Benneworth, P. (2006), "Where and What is the North East of England?", in Hardill, I., Benneworth, P., Baker, M. and Budd, L. (Eds), The Rise of the English Regions?, Routledge, London, pp.107-119.

Cassiman, B. and Veugelers, R. (2000), "R\&D Cooperation and Spillovers: Some Empirical Evidence from Belgium”, American Economic Review, vol.92, pp.1169-1184.

Chesbrough, H. (2003), Open Innovation, Harvard Business School Press, Boston.

Cohen, W.M. and Klepper, S. (1996), “A Reprise of Size and R\&D”, The Economic Journal, vol.106, pp.925-951.

Cohen, W.M. and Levin, R.C. (1989), "Innovation and Market Structure”, in Schmalensee, R. and Willig, R. (Eds.), Handbook of Industrial Organization, Elsevier Science, Amsterdam, pp.1059- 1107.

Cohen, W.M. and Levinthal, D.A. (1990), “Absorptive Capacity: New Perspective on Learning and Innovation”, Administrative. Science Quarterly, vol.35, pp.128-152. 
Colombo, M.G., Delmastro, M. and Grilli, L. (2004), "Entrepreneurs' Human Capital and the Start-up Size of New Technology-based Firms", International Journal of Industrial Organization, vol.22, pp.1183-1211.

Colombo, M.G. and Grilli, L. (2005), "Founders' Human Capital and the Growth of New Technology-based Firms: a Competence-based View”, Research Policy, vol.34, pp.795-816.

Cooke, P. (2001), "Regional Innovation Systems, Clusters, and the Knowledge Economy", Industrial and Corporate Change, vol.10, pp.945-974.

Cooke, P., Gómez Uranga, M. and Etxebarria, G. (1997), "Regional Innovation Systems: Institutional and Organisational Dimensions", Research Policy, vol.26, pp.475-491.

Criscuolo, C. and Haskel, J.E. (2003), "Innovation and Productivity Growth in the UK: Evidence from the CIS2 and CIS3", Centre for Research into Business Activity Working Paper.

D'Este, P., Iammarino, S., Savona, M. and von Tunzelmann, N. (2008), "What Hampers Innovation? Evidence from the UK CIS4", SPRU Electronic Working Paper Series (SEWPS), no. 168 (February).

Evangelista, R., Iammarino, S., Mastrostefano, V. and Silvani, A. (2002), "Looking for Regional Systems of Innovation: Evidence from the Italian Innovation Survey”, Regional Studies, vol.36, pp.173-186.

Faems, D., Van Looy, B. and Debackere, K. (2005), "The Role of Inter-organizational Collaboration within Innovation Strategies: Towards a Portfolio Approach”, Journal of Product Innovation Management, vol.22, pp.238-250.

Filatotchev, I., Piga, C., and Dyomina, N. (2003), "Network Positioning and R\&D Activity: A Study of Italian Groups”, R\&D Management, vol.33, pp.37-48.

Fritsch, M. and Lukas, R. (2001), "Who Cooperates on R\&D”, Research Policy, vol.30, pp.297312.

Gore T. and Jones, C. (2006), "Yorkshire and the Humber", in Hardill, I., Benneworth, P., Baker, M. and Budd, L. (Eds), The Rise of the English Regions?, Routledge, London, pp.137-155.

Gray, M., Martin, R. and Tyler, P. (2006), "The East of England: A Nebulous Region in Transition”, in Hardill, I., Benneworth, P., Baker, M. and Budd, L. (Eds), The Rise of the English Regions?, Routledge, London, pp.184-203.

Green, A. and Berkeley, N. (2006), “The West Midlands: the 'Hinge' in the Middle”, in Hardill, I., Benneworth, P., Baker, M. and Budd, L. (Eds), The Rise of the English Regions?, Routledge, London, pp.156-167.

Hardill, I., Bentley, C. and Cuthbert, M. (2006) “The East Midlands: The Missing Middle?”, in Hardill, I., Benneworth, P., Baker, M. and Budd, L. (Eds), The Rise of the English Regions?, Routledge, London, pp.168-183.

Hobday, M. (1995), Innovation in East Asia: the Challenge to Japan, Edward Elgar, London.

Howells, J. (1999), “Regional Systems of Innovation?”, in Archibugi, D., Howells, J. and Michie, J. (Eds), Innovation Policy in a Global Economy, Cambridge University Press, Cambridge, pp.67-93.

Iammarino, S. (2005), “An Evolutionary Integrated View of Regional Systems of Innovation: Concepts, Measures and Historical Perspectives”, European Planning Studies, vol.13, pp.495-517.

Iammarino, S. and McCann, P. (2009), Multinationals and Economic Geography: Location, Technology, and Innovation, Princeton University Press, in progress.

Iammarino, S., Padilla R. and von Tunzelmann N. (2008), "Technological Capabilities and Global-local Interactions: The Electronics Industry in Two Mexican Regions", World Development, vol.36, pp.1980-2003.

Kleinknecht, A. and Reijnen, J.O.N. (1991), "More Evidence on the Undercounting of Small Firm R\&D”, Research Policy, vol.20, pp.579-587. 
Kline, S.J. and Rosenberg, N. (1986), “An Overview of Innovation”, in Landau, R. and Rosenberg, N. (Eds), The Positive Sum Strategy: Harnessing Technology for Economic Growth, National Academy Press, Washington DC, pp.275-306.

Lall, S. (1992), “Technological Capabilities and Industrialization”, World Development, vol.20, pp.165-186.

Lall, S. (1998), "Exports of Manufactures by Developing Countries: Emerging Patterns of Trade and Location", Oxford Review of Economic Policy, vol.11, pp.54-73.

Laursen, K. and Salter, A.J. (2004), "Searching Low and High: What Types of Firms Use Universities as a Source of Innovation?”, Research Policy, vol.33, pp.1201-1215.

Laursen, K. and Salter, A.J. (2006), “Open for Innovation: The Role of Openness in Explaining Innovation Performance among UK Manufacturing Firms”, Strategic Management Journal, vol.27, pp.131-150.

Lundvall, B.A. (1988), "Innovation as an Interactive Process: From User-producer Interaction to the National System of Innovation”, in Dosi, G., Freeman, C., Nelson, R., Silverberg, G. and Soete, L. (Eds), Technical Change and Economic Theory, Pinter, New York, pp.349-369.

Machin, S. and Van Reenen, J. (1998), “Technology and Changes in the Skill Structure: Evidence from Seven OECD Countries”, Quarterly Journal of Economics, vol.113, pp.1215-1244.

Malerba, F (1992), "Learning by Firms and Incremental Technical Change", The Economic Journal, vol.102, pp.845-859.

Miotti, L. and Sachwald, F. (2003), "Co-operative R\&D: Why and With Whom? An Integrated Framework of Analysis”, Research Policy, vol.32, pp.1481-1499.

Narula, R. and Zanfei, A. (2003), “The International Dimension of Innovation”, in Fagerberg, J., Mowery, D.C. and Nelson, R.R. (Eds), The Oxford Handbook of Innovation, Oxford University Press, Oxford, pp. 318-345.

Nelson, R.R. and Winter, S.G. (1982), An Evolutionary Theory of Economic Change, Harvard University Press, Cambridge, MA.

Newman, A. and Thornley, N. (2005), Planning World Cities: Globalization and Urban Politics, Palgrave Macmillan, New York.

OECD (2005), Oslo Manual, OECD, Paris.

Piga, C. and Vivarelli, M. (2003), "Sample Selection in Estimating the Determinants of Cooperative R\&D”, Applied Economics Letters, vol.10, pp.243-246.

Piga, C. and Vivarelli, M. (2004), “Internal and External R\&D: A Sample Selection Approach”, Oxford Bulletin of Economics and Statistics, vol.66, pp.457-482.

Piva, M., Santarelli, E. and Vivarelli, M. (2005), "The Skill Bias Effect of Technological and Organisational Change: Evidence and Policy Implications”, Research Policy, vol.34, pp.141157.

Piva, M. and Vivarelli, M. (2004), "The Determinants of the Skill Bias in Italy: R\&D, Organisation or Globalisation?”, Economics of Innovation and New Technology, vol.13, pp.329-347.

Piva, M. and Vivarelli, M. (2009), “The Role of Skills as a Major Driver of Corporate R\&D”, International Journal of Manpower, forthcoming.

Romijn, H. (1999), Acquisition of Technological Capability in Small Firms in Developing Countries, Macmillan, Basingstoke.

Schumpeter, J. (1943), Capitalism, Socialism and Democracy, Unwin University Press, London.

Schienstock, G. (2009), “Organisational Innovations and New Knowledge Management Practices, their Diffusion and Influence on Firm Performance: Results from a Finnish Firm Survey”, IAREG Working Paper, no. 1.2.d, April.

Simonen, J. and McCann, P. (2008), "Firm Innovation: The Influence of R\&D Cooperation and the Geography of Human Capital Inputs”, Journal of Urban Economics, vol.64, pp.146-154. 
Storey, D.J. and Tether, B.S. (1998), "New Technology-based Firms in the European Union: An Introduction”, Research Policy, vol.26, pp.933-946.

Vanhaverbeke, W.P.M., Duysters, G.M. and Beerkens, B.E. (2002), "Technology Capability Building through Networking Strategies within High-tech Industries”, Academy of Management Papers, Denver CO.

von Hippel, E. (1988), The Sources of Innovation, Oxford University Press, New York.

von Tunzelmann, N. (2009), "Regional Capabilities and Industrial Regeneration", in Farshchi, M., Janne, O. and McCann, P. (Eds), Technological Change and Mature Industrial Regions: Firms, Knowledge and Policy, Edward Elgar, Cheltenham, pp.11-28.

von Tunzelmann, N. and Wang, Q. (2003), “An Evolutionary View of Dynamic Capabilities”, Economie Appliquée, vol.6, pp.33-64.

von Tunzelmann, N. and Wang, Q. (2007), "Capabilities and Production Theory”, Structural Change and Economic Dynamics, vol.18, pp.192-211.

Westphal, L.E., Kritayakirana, K., Petchsuwan, H., Sutabutr and Ythavong, Y. (1990), "The Development of Technological Capability in Manufacturing: A Macroscopic Approach to Policy Research”, in Evenson, R.E. and Ranis, G. (Eds), Science and Technology: Lessons for Development Policy, Intermediate Technology Publications, London, pp.81-134.

Wignaraja, G. (2002), "Firm Size, Technological Capabilities and Market-oriented Policies in Mauritius", Oxford Development Studies, vol.30, pp.87-104.

Wilson, C. and Baker, M. (2006), “The North West: Cultural Coherence and Institutional Fragmentation”, in Hardill, I., Benneworth, P., Baker, M. and Budd, L. (Eds), The Rise of the English Regions?, Routledge, London, pp.120-136. 


\section{Appendix 1 - List of variables}

\begin{tabular}{|l|l|}
\hline NAME & NATURE \\
\hline Dependent variable & \\
\hline Technological status of the firm: & Categorical ordered \\
\hline Technologically inactive firm = 0 & \\
\hline Firm with technological competences = 1 & \\
\hline Firm with technological capabilities = & \\
\hline & \\
\hline Independent/control variables & \\
\hline Cooperation partners & Dummies \\
\hline A: other enterp. within firm's group LOCAL & \\
\hline A: other enterp. within firm's group NOT LOCAL & \\
\hline B: suppliers LOCAL & \\
\hline B: suppliers NOT LOCAL & \\
\hline C: clients LOCAL & \\
\hline C: clients NOT LOCAL & \\
\hline D: competitors LOCAL & \\
\hline D: competitors NOT LOCAL & \\
\hline E: consultants LOCAL & \\
\hline E: consultants NOT LOCAL & \\
\hline F+G: universities\&pub.res. LOCAL & \\
\hline F+G: universities\&pub.res. NOT LOCAL & \\
\hline & \\
\hline Size: Ln(Employment) & \\
\hline Group & Continuous \\
\hline Internationalisation & Dummy \\
\hline Start-up & Dummy \\
\hline Human capital & Dummy \\
\hline & Continuous \\
\hline Sectors & \\
\hline Primary sector & Dummies \\
\hline Engineering-based manuf. & \\
\hline Other manufacturing & (base) \\
\hline Construction & \\
\hline Retail \& distribution & \\
\hline Knowledge-intensive services & \\
\hline Other services & \\
\hline & \\
\hline Regions & \\
\hline North England (North East, North West, Yorkshire and the Humber) & \\
\hline Midlands (East Midlands, West Midlands) & \\
\hline Eastern England & \\
\hline London & \\
\hline South England (South East, South West) & \\
\hline Wales & \\
\hline Scotland & \\
\hline Northern Ireland & \\
\hline & \\
\hline
\end{tabular}


Appendix 2: Sectoral distribution of the categorical dependent variable - number of firms and relative percentage (in brackets)

\begin{tabular}{|c|c|c|c|c|c|c|c|}
\hline & $\begin{array}{l}\text { Primary } \\
\text { sector }\end{array}$ & $\begin{array}{c}\text { Engineering- } \\
\text { based } \\
\text { manufacturing }\end{array}$ & $\begin{array}{c}\text { Other } \\
\text { manufacturing }\end{array}$ & Construction & $\begin{array}{c}\text { Retail \& } \\
\text { distribution }\end{array}$ & $\begin{array}{c}\text { Knowledge- } \\
\text { intensive } \\
\text { services } \\
\end{array}$ & $\begin{array}{c}\text { Other } \\
\text { services }\end{array}$ \\
\hline $\begin{array}{l}\text { Firm } \\
\text { technological } \\
\text { inactive } \\
\text { (value 0) }\end{array}$ & $\begin{array}{c}102 \\
(45.13)\end{array}$ & $\begin{array}{c}433 \\
(20.89)\end{array}$ & $\begin{array}{c}597 \\
(22.50)\end{array}$ & $\begin{array}{c}724 \\
(51.28)\end{array}$ & $\begin{array}{c}1,154 \\
(46.18)\end{array}$ & $\begin{array}{c}672 \\
(26.20)\end{array}$ & $\begin{array}{c}1,626 \\
(43.65)\end{array}$ \\
\hline $\begin{array}{l}\text { Firm with } \\
\text { technological } \\
\text { competences } \\
\text { (value 1) }\end{array}$ & $\begin{array}{c}69 \\
(30.53)\end{array}$ & $\begin{array}{c}586 \\
(28.27)\end{array}$ & $\begin{array}{c}778 \\
(29.33)\end{array}$ & $\begin{array}{c}444 \\
(31.44)\end{array}$ & $\begin{array}{c}620 \\
(24.81)\end{array}$ & $\begin{array}{c}572 \\
(22.30)\end{array}$ & $\begin{array}{c}1,036 \\
(27.81)\end{array}$ \\
\hline $\begin{array}{l}\text { Firm with } \\
\text { technological } \\
\text { capabilities } \\
\text { (value 2) }\end{array}$ & $\begin{array}{c}55 \\
(24.34)\end{array}$ & $\begin{array}{c}1,054 \\
(50.84)\end{array}$ & $\begin{array}{c}1,278 \\
(48.17)\end{array}$ & $\begin{array}{c}244 \\
(17.28)\end{array}$ & $\begin{array}{c}725 \\
(29.01)\end{array}$ & $\begin{array}{c}1,321 \\
(51.50)\end{array}$ & $\begin{array}{c}1,063 \\
(28.54)\end{array}$ \\
\hline Total & 226 & 2,073 & 2,653 & 1,412 & 2,499 & 2,565 & 3,725 \\
\hline
\end{tabular}

